\title{
New Media Era News Dissemination Education Development Research
}

\author{
Yuchen Liu \\ Qujing normal college, Yunnan qujing city kirin Sanjiang Avenue, 655011
}

\author{
Keywords: News Transmission; Media era; Information tools; Education concept
}

\begin{abstract}
. today's news and information in the age of new media, in the face of so many news and information, people are paying more attention to the development of journalism and communication education. In the construction of news dissemination system, should use the advanced technology, make information can rapid spread, covering the scope of further expansion, news information should pay attention to the original rate, a lot also should pay attention to the rates of starting and fall to the ground. On education of journalism and communication personnel, efforts should be made to them grow into a high level of high quality talents, can carry on the news spread interdisciplinary innovation.
\end{abstract}

\section{New Media Era News Dissemination Education Development Present Situation}

As news spread carrier, such as the popularity of the TV, Internet, mobile phones, journalism and communication to achieve the universal. Journalism is no longer the traditional content, but after screening and processing on the content of the news release. On the transmission time, show the information real-time, broke the persistent existence of traditional media. Is the same as the economic globalization, information have appeared in the globalization, information transmission broke the traditional limitations. In the news and information on side, focus on scope of news information into all walks of life. At the same time, professionalization and capitalization of news media constantly forming, and derived the related industries.

With the increase of news information, validity and originality of news and information, such as demand has increased, so the requirement of news also have improved, need to understand and familiar with various news carrier, this is determined by the journalism and communication market. News talents needs to have social sense of responsibility and professionalism, in order to better guarantee the accuracy and authenticity of the news and information, to adapt to the needs of the new media age. When he worked in journalism and communication, need to learn how to communicate with other industries, efforts to become creative talents.

With the advent of new media, traditional journalism education is more and more cannot satisfy the needs of social development, so the need for reform. In traditional journalism and communication education, the backward education idea and utilitarian education of journalism and communication education emphasizes on deviation, cultivating talents in different news lacking quality aspect, will eventually be eliminated by the society. Journalism education courses also cannot very good meet, performance in the course of relative single, the news talents' innovation spirit and academic education is not perfection.

\section{New Media Age the Development Direction of Journalism and Communication Education}

The early reform and opening up, China's news education discipline is relatively single, content is not flexible, is relatively rigid, adopt centralized management, coupled with the relatively small number of education institutions, so in the cognition of news propagation is relatively similar, lack of innovation. The factors cause the reason besides inheriting the history of the past, the party's education policy and national policy formulation is also related. As news education workers, I think the development of journalism education should pay attention to the following aspects:

First, the Authenticity and Rationality. Along with the development of The Times, people begin to focus on journalism and communication education, corresponding attitude change, also related personnel by the development of journalism and communication at home and abroad for the 
research and analysis, and has carried on the summary below.

Politically, the news spread can carry on the transfer to the construction of a harmonious society this goal, and played an important role; On the economy, with the development of informatization, is the rapid development of knowledge economy, people pay more and more attention to information economy, through the news spread, can effectively drive the social and economic development. ; Culturally, the news spread to everyone present gaming colorful art feast, can promote the development of advanced culture; Internationally, journalism and communication as a soft competitiveness, can very good spread the image of the country, make the mutual understanding between the countries to strengthen cooperation and communication, so I need to do a good job of news dissemination.

By above can see, in the journalism and communication education, should respect the laws of each course, with the development of era, the traditional subject to consolidate and strengthen the work on the basis of strengthening the study of a new discipline, and efforts with the international practice, cultivating high-quality innovative talents, the higher spread the news and information, to improve its influence, strengthen the cooperation and communication with others, constantly improve themselves.

Second, Dissemination Environment Adaptation. Journalism and communication education in our country is relatively backward, relatively in practical, realistic and application talented person's need is relatively low, in the face of fierce competition and challenges from every aspect, media need to be reasonable to respond, otherwise it will be hard to survive in the media industry, very passive. People familiar with the corresponding solving measures according to these situation, such as increasing the corresponding professional subjects, professional subjects also made corresponding change, set up to meet the market demand and highly professional spirit cultivation goal. Department of journalism and communication education actively adjust themselves, according to the change of news market change to adjust to changes in the news market. Pay attention to the cultivation of journalism talents with professional skills, wide range of adapt to the working face, expand the scope of work, constantly adapt to environmental changes of news and media education.

In addition, education staff can also weaken the line between professional and reduce professional required courses and increasing professional basic course for students in journalism and communication education, students can gain more when choosing professional basic knowledge, can also have a lot of choice of direction, this will also be able to develop adaptive talent.

Third, Beyond Class Limits. Journalism education can not only confined to education in writing, this is only an armchair strategist, so we should in journalism and communication education in strengthening practical and real practice. In education, improve the student's ability, realize the unification of the theory and practice.

Journalism and communication education in our country should go beyond the limitations of the classroom, the classroom learning theory ability, through many practice activities to improve themselves, actually for the core and main point of news propagation of feeling and understanding. At the same time improve the complex ability of students, an inter-bank homework. By "interdisciplinarity" with the skill of service "entire media", realize self-worth. At the same time, another kind of form beyond the limit of class is to go abroad, towards the world, with the spread of international news communication these understanding.

Fourth, the Transformation of the Media Group. Journalism education institutions can cooperate with radio station, founded by a radio program to strengthen the student's exercise, can make the students to learn knowledge to digest. Schools can through integration with other media unit, jointly to the school, in school can be creative, production, dissemination of cultural products, etc., make the function of media group reflected in the campus. Through the substantial cooperation between the two, set up the news dissemination education new chapter in China.

\section{Conclusion}

In the era of new media, journalism and communication education work of our country still has a long way to go, should broaden the journalism and communication involves the field of education, 
vigorously promote the innovation of the journalism and communication education activities, for our country to cultivate a large number of innovative high-quality journalism talents.

\section{References}

[1] Yuan Xue. Under the background of globalization of news dissemination and the national image publicity way [J]. Journal of western radio and television, 2015 (14) : 47-48.

[2] Ming ouyang, Ma Jinghua Xu Shuang, vivi. A master's degree in journalism culture dilemma and change [J]. Journal of China press, 2009 (4) : 28.

[3] Deleuze (method). Time, image, movie [M]. Xie Jiang, etc., eds. Hunan fine arts publishing house, 2004:229-230.

[4] jun-fei du. Education in journalism and communication of China: where to go [J]. Journal of communication and society of Hong Kong, 2009 (1) : 78.

[5] high. Under the trend of media convergence thinking [J]. Chinese journalistic education reform of journalism, a collection of 2013 (1) : 141.

[6] jian-xiong zeng, Ceng Jun Deng Wenyan. News spread kind of graduate student education crisis and the connecting - deep thinking about change the domestic graduate student training mode [J]. Modern communications, 2010 (3) : 126-127. 